UDC 811.163.41’367.625.3

UDC 811.511.141’367.625.3

https://doi.org/10.18485/ms_zmsfil.2021.64.2.10

Изворни научни рад

Душанка Звекић-Душановић

\title{
О НЕКИМ АСПЕКАТСКИМ АЛТЕРНАЦИЈАМА У МАЂАРСКОМ И СРПСКОМ ЈЕЗИКУ
}

\begin{abstract}
У раду се описује један мањи сегмент проблематике глаголског вида и аспекта на релацији мађарски - српски језик. Прихватајући став мађарских лингвиста да се аспекат испољава на реченичном нивоу, те да на његову интерпретацију утичу различита синтаксичка средства, у раду се истражује утицај типа спацијалне одредбе на реченични аспекат. Анализи су подвргнути мађарски глаголи за означавање положаја тела áll, $\ddot{u} l$ и fekszik, којима у српском одговарају индирективни глаголи $c \bar{u} a j a \bar{u} u, c e g e \bar{u} и$ и ле-

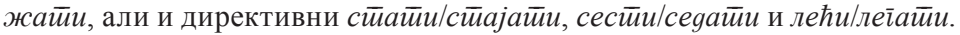

Кључне речи: српски језик, мађарски језик, контрастивна анализа, глаголски вид, глаголски аспект, спацијалност.
\end{abstract}

This paper describes a small segment of the problematics concerning verb aspect and Aktionsart in the relation Hungarian - Serbian. Accepting the opinion of Hungarian linguists that aspect is realized on the sentential level and that its interpretation is conditioned by different syntactic means, the paper investigates the influence of the types of spatial adjuncts on the sentential aspect. The analysis encompasses the Hungarian verbs expressing bodily posture áll, $\ddot{u} l$ and fekszik, whose Serbian counterparts are indirective verbs stajati, sedeti and ležati, but also the directive ones stati/stajati, sesti/sedati i leći/legati.

Key words: Serbian, Hungarian, contrastive analysis, verb aspect, Aktionsart, spatiality.

1. Увод. Мађарски и српски језик у многоме се разликују када је у питању исказивање глаголског вида/аспекта. Разлике у систему ова два језика одражавају се на тумачење овог феномена, његову типологију и терминологију.

У фокусу овога рада јесте опис једног мањег сегмента ове проблематике - утицај типа спацијалне одредбе на аспекатску интерпретацију синтаксичких структура с мађарским глаголима којима се означава положај тела ('testtartást kifejező igék' (SIPOs 2019: 299)), као што су áll, ül и fekszik. Полазећи, дакле, од мађарског језика показаће се у којим се синтаксичко-семантичким

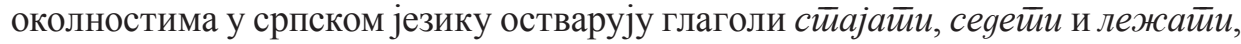

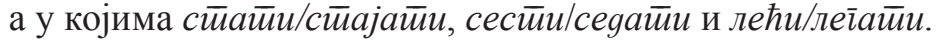

Примери за овај рад преузети су из електронске базе података мађарских глагола с допунама Mazsola - a magyar igei bövítményszerkezet vizsgálata, као и из мађарских студија које се баве овом проблематиком. Мађарски примери наводе се без измена како би се сачувала њихова оригиналност, а превод на српски је аутора овог рада уз проверу од стране изворних говорника мађарског и српског језика.

2. О ГЛАГОЛСКОМ ВИДУ И РЕЧЕНИЧНОМ АСПЕКТУ. И У српском и У мађарском језику постоје глаголи имперфективног и перфективног вида. Најчешће средство перфективизације у оба језика јесте префиксација, што се може илустровати следећим примерима: 
(1) Olvasta az újságot. (KIEFER 2015: 730)

(1a) Читиао је новине.

(2) Elolvasta az újságot. (KIEFER 2015: 730)

(2а) Прочит̄ао је новине.

Ипак, у мађарском је честа појава да се глаголима имперфективног вида исказује завршена радња. На то утичу различита синтаксичка средства, па и шири реченични контекст:

(3) Írt egy levelet. (KIEFER 2015: 730)

(3а) Писао је писмо.

(4) Írt egy levelet és hazament. (KIEFER 2015: 730)

(4a) Найисао је писмо и отишао кући.

Сматра ce (KIEFER 2015: 730) да је глагол и у реченици (3) и у реченици (4) имперфективан, али да је у реченици (4) исказана довршена (перфективна) радња.

Показујући ову ситуацију на различитим примерима Кифер (KIEFER 2015: 730) долази до закључка да се категорија свршености/несвршености не односи само на глаголе, већ зависи од читаве реченице. Зато, уместо о глаголском виду, говори о аспекту, који је синтаксичко-семантичка категорија. Сматра да су аспекатске категорије универзалне, а да се разлика између аспекатских и неаспекатских језика огледа у различитим језичким нивоима на којима се ова појава испољава, морфолошким или синтаксичким. Констатује, такође, да су 'чисти случајеви' ретки. Тако, према његовом мишљењу, мађарски језик није 'чисто аспекатски језик' у смислу да на реченични аспекат утичу и морфологија глагола и синтаксички елементи.

Једно од средстава перфективизације у мађарском језику јесте и одговарајући тип спацијалне одредбе. Ф. Кифер (KIEFER 2015: 772) ову појаву илуструје следећим примерима:

(5) Józsi futott. (KIEFER 2015: 772)

(5а) Јожи је йрчао.

(6) Józsi a konyhába futott. (KIEFER 2015: 772)

(6а) Јожи је ойрчао/уйрчао у кухињу.

Кифер (KIEFER 2015: 772) примећује да именска реч с лативним наставком - $b a /$-be истовремено одређује и смер кретања и његов циљ, крајњу тачку. Синтагма a konyhába fut (у примеру (6)) означава усмерену и ограничену активност, те је ситуација њоме означена свршеног аспекта, док је она у реченици (5) несвршеног аспекта. У српском се ова разлика одражава тако што је еквивалент глагола fut без спацијалне одредбе имперфективни глагол $\bar{u} р ч а \bar{u} и$ (пример 5а), за разлику од синтагме с лативном одредбом, којој од-

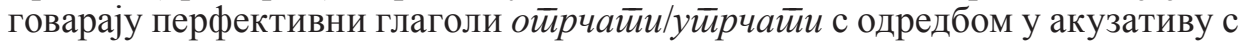
предлогом y (пример 6а).

3. О СИСТЕМУ СПАЦИЈАЛНИХ ОДРЕДБИ У СРПСКОМ И МАЂАРСКОМ ЈЕЗИКУ. Мађарски језик карактерише тзв. 'тројност правца' (irányhármasság), појава која је најдоследнија у обележавању просторних односа. На основу питања 
ogaкле (honnan), ìge (hol) и кyga (hová) постављена је и структура мађарских адвербијала. Одредбе за место се у мађарском најчешће исказују именским речима с падежним наставцима или постпозицијама. ${ }^{1}$ Већина падежних наставака и постпозиција управо и постоје у три варијанте, обележавајући на тај начин наведену 'тројност’:

\begin{tabular}{|c|c|c|}
\hline $\begin{array}{c}\text { АБЛАТИВ } \\
\text { Előzményhatározók }\end{array}$ & $\begin{array}{c}\text { ЛОКАТИВ } \\
\text { Tartamhatározók }\end{array}$ & $\begin{array}{c}\text { ЛАТИВ } \\
\text { Véghatározók }^{4}\end{array}$ \\
\hline 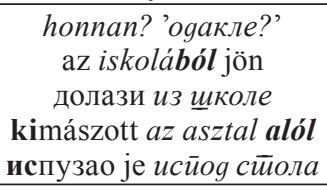 & 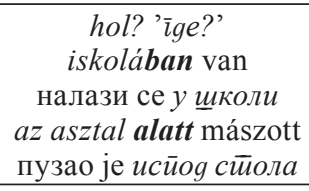 & $\begin{array}{c}\text { hová? 'кyga?' } \\
\text { iskolába megy } \\
\text { одлази } u \text { školu } \\
\text { bemászott az asztal alá } \\
\text { упузао је ūog cūo }\end{array}$ \\
\hline
\end{tabular}

У новијој српској лингвистичкој литератури семантичка структура синтаксичких јединица са спацијалним значењем описује се укрштањем два параметра: позиционог и динамичког (Антонић 2005; ПипеР 2005; ПАвловић 2006). Позициони параметар односи се на утврђивање позиције објекта локализације у односу на локализатор, при чему се може разликовати локациона и оријентациона концепција спацијалности. Динамичким се аспектом упућује на промену позиције објекта локализације, карактерише га опозиција индирективност - директивност, а у оквиру директивности разликовање аблативности и адлативности. Показаће се да је за тумачење семантике синтаксичких структура које су предмет овога рада релевантан управо динамички аспект.

У примерима датим у табели 1 . уочава се и семантичка компатибилност глагола и спацијалне одредбе. Семантика глагола јӧn (gолазитии) захтева аблативну, van (налазитии се) локативну, а теgy (оgлазийи) лативну спацијалну одредбу. Некада је управо префикс сигнал одређеног типа директивности. Тако је глагол с префиксом $k i$ - (из-) компатибилан с аблативном, а глагол с префиском be- (y-) с лативном одредбом. Неретко, ипак, сама семантика глагола није довољно прозирна да би се, без контекста, могла предвидети њихова динамичка обележја.

4. О СТАТИЧНОСТИ/ДИНАМИЧНОСТИ ГЛАГОЛА ÁLL, ÜL И FEKSZIK. Т. ФорГач (ForgÁCs 1996: 57-58) глаголе посматра из перспективе теорије валенције. Према његовом мишљењу глаголи áll, ül и fekszik располажу с три рекцијске структуре:

(7) Péter áll/ül/fekszik. (Forgács 1996: 57)

(7a) Петар стоји/седи/лежи.

\footnotetext{
${ }^{1}$ У овом раду се неће разматрати друга језичка средства за исказивање спацијалности.

${ }^{2}$ E. Андрић (ANDRIĆ 2002: 140-173) под 'локативним падежима' подразумева групу падежних наставака чија је примарна функција обележавање месног или временског односа, независно од критеријума 'тројности правца'.

${ }^{3}$ Термин 'латив' употребљава J. Вајда (VAJDA 1976: 12). У српској литератури више је познат под називом 'адлатив' (Пипер ет al. 2005; ПАвловић 2006).

${ }^{4}$ Термини су преузети од Б. Кеслер (KeSZLER 2000: 430).
} 
(8) Péter valahol áll/ül/fekszik. (ForGÁcs 1996: 57)

(8a) Петар негде стоји/седи/лежи.

(9) Péter valahová áll/ül/fekszik. (ForGÁcs 1996: 57)

(9a) Петар некуда стаје/седа/леже.

Прва два примера представљају статичке конструкције и могу се посматрати као једна структура с факултативним проширком. Разликују се, ипак, у томе што је у првом акценат на самој ситуацији (Péter áll = nem ül, fekszik, megy stb. - Петиар стиоји = не cеgи, лежи, иgе и сл.), док је у другом акценат управо на месту на којем се она одвија. Трећа је конструкција, према Форгачу, динамична. Овај се аутор не бави аспекатским питањем ових структура.

Разматрајући веома подробно феномен аспекта у мађарском језику Б. Немет (NÉмETH 2012) посебну пажњу обраћа на статичност. Ауторка уочава везу између статичности и семантике глагола стања. Једно од својстава стања јесте инхерентна перзистенција, чија је суштина, према ауторки, у томе да постојање/одржавање стања не захтева улагање енергије од стране неког агенса, при чему прекид стања махом настаје услед неког спољашњег утицаја (NÉмETH 2012: 114). Говорећи о инхерентној перзистенцији разматра

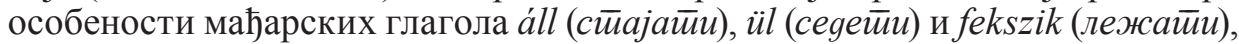
глагола који се могу сврстати у категорију тзв. динамичких стања. Наиме, ове глаголе стручна литература често убраја у специфичну врсту глагола стања. Уколико се инхерентна перзистенција сматра једним од основних кри-

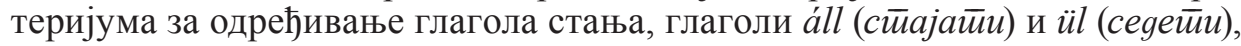
сматра ауторка, не могу се сврстати у стања, већ најпре у групу хомогених процеса, будући да стајање и седење захтевају улагање одређене енергије. Од ових се разликује појам лежања које не захтева улагање енергије, те се на основу приказаног критеријума глагол fekszik (лежайu) може сврстати међу стања. Б. Немет даје следеће примере:

(10) Anna a kapuban állt. (NÉMETH 2012: 114)

(10а) Ана је стајала у капији.

(11) Pisti a földön ült. (NÉMETH 2012: 114)

(11a) Пишти је седео на земљи.

(12) A kisfiú a fa tövében feküdt. (NÉmETH 2012: 114)

(12a) Дечак је лежао у подножју дрвета.

На основу датог тумачења и наведених примера може се закључити да је Б. Немет имала у виду само статичке конструкције.

И Ф. Кифер (KIEFER 2015: 743-744) уочава специфична обележја ових глагола. Сматра да они припадају прелазној категорији, имају карактеристике и глагола стања, али и радње и збивања. Наиме, глаголе стања карактерише временски интервал који се не може прекинути, што не важи за наведене глаголе. Временска структура ових глагола допушта прекид. Ову карактеристику појашњава следећим примерима:

(13) Pisti egész este ott állt a sarkon. (KIEFER 2015: 743)

(13a) Пишти је цело вече стајао на ћошку. 
(14) Anna egész nap az ágyban feküdt. (KIEFER 2015: 743)

(14a) Ана је цео дан лежала у кревету.

Према Ф. Киферу, прва реченица садржи истиниту тврдњу и ако временски интервал о којем је реч важи и за периоде у којима Пишти није стајао на ћошку. Тако и друга реченица остаје истинита и ако је Ана током дана више пута устала из кревета. Ово својство их, каже Кифер, приближава динамичким глаголима. Као што се из примера и објашњења види, он на овом месту не повезује тип спацијалне одредбе с динамичким/нединамичким карактеристикама ове групе глагола.

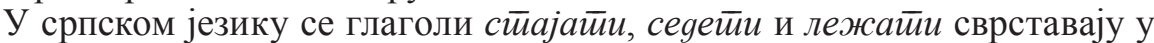
глаголе стања (Mrazović 2009: 69; ПиПеР - КлАлн 2013: 149). С друге стране,

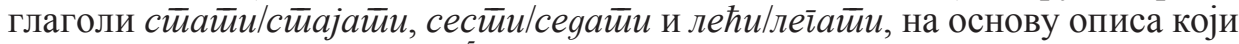
даје П. Мразовић (2009: 69), ${ }^{5}$ могу се сврстати у глаголе за означавање рад-

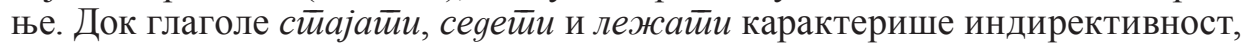

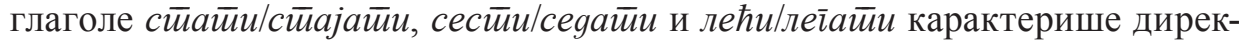
тивност, која је специфична утолико што припадају глаголима тзв. глаголима смештања, тј. глаголима финалне директивности, односно глаголима с ослабљеном моториком. Заправо се ови глаголи налазе на граници између директивних и индирективних глагола. Њима „се денотира завршница усмереног кретања, односно почетак мировања у простору” (ПАвловић 2006: 21).

5. ПРИКАЗ ГРАЂЕ. Преглед ових језичких средстава за исказивање просторних односа и њихових српских еквивалената налазимо код Ј. Вајде (VAJDA 1976) и Е. Андрић (ANDRIĆ 2002; 2008). У наставку ће се узети у обзир њихови налази. Где год је то могуће, тј. ако су заступљени у корпусу, дају се примери у садашњем и прошлом времену како би се видело да ли темпорални аспект утиче на видску интерпретацију. Приказане су оне синтаксичко-семантичке структуре које су пронађене у корпусу и које су комбинабилне са семантиком посматраних глагола.

\section{1. ЛОКАТИВНЕ (ИНДИРЕКТИВНЕ) КОНСТРУКЦИЈЕ}

5.1.1. Наставком -ban/-ben (наставак за инесив) означава се унутрашњи просторни однос. За глаголе у овом раду релевантно је да се њиме изражава стање мировања. У српском му је типичан еквивалент конструкција $y+$ локатив, којом се упућује на унутрашњост локализатора, при чему глаголи уз које стоји имају обележја динамичност (+/-) и директивност (-) (Антонић 2005: 283):

(15) Az előszobában álltunk.

(15a) Стајали смо у предсобљу.

(16) Iza ott áll a szobában...

(16а) Иза стоји у соби...

${ }^{5}$ П. Мразовић глаголе којима се означава радња дефинише на следећи начин: „вољна, свесна физичка или психичка активниост вршиоца радње (у реченици субјекта), активност која се најчешће врши с одређеним циљем, при чему увек постоји могућност да се радња изврши или не" (Mrazović 2009: 69).

${ }^{6}$ Будући да мађарски језик не познаје граматички род, приликом превођења се није могло знати који је род у питању. Определила сам се за мушки род као неутралан. 
(17) A cukrászdában ültek.

(18) ...ül a csónakban...

(19) A szobámban feküdtem...

(20) Az ágyban fekszik... (17a) Седели су у посластичарници.

(18a) ...седи у чамцу...

(19a) Лежао ${ }^{6}$ сам у својој соби.

(20а) Лежи у кревету...

5.1.2. Наставком -n/-on/-en/-ön (наставак за супресив) означава се спољашњи просторни однос. За наше примере релевантно је да се њиме изражава површина на којој се нешто налази у стању мировања. У српском му је типичан еквивалент $н a+$ локатив, којим се упућује на горњу површину локализатора, такође се јавља уз глаголе с обележјима динамичност (+/-) и директивност (-) (Антонић 2005: 283):

(21) Álltam a hegyen...

(22) ...a küszöbön áll...

(23) A hátsó ülésen már ül valaki.

(24) Az ágy szélén ült...

(25) A felső ágyon fekszik...

(26) ... feküdt a földön... (21a) Стајао сам на брду...

(22a) ...стоји на прагу...

(23a) На задњем седишту неко већ седи.

(24a) Седео је на ивици кревета...

(25a) Лежи на горњем кревету...

(26а) ...лежао је на земљи...

5.1.3. Наставком -náll-nél (наставак за адесив) означава се шири степен спољашњих просторних односа. Такође може изражавати стање мировања у близини појма обележеног овим падежом. У српском су му еквиваленте предлошко-падежне конструкције коg/близу/кpaj/go/ūopeg + генитив, уз + акузатив и за + инструментал. И. Антонић (2005: 148) генитив с овим предлозима сврстава у конструкције којима се исказује неусмереност, док код С. Павловића (2006: 50) налазимо да су директивно неутралне. С обзиром на критеријум статичан/динамичан глагол, предлози go и коg захтевају статичан глагол, а предлози крај и $\bar{u} о p e g$ дозвољавају и статичан и динамичан глагол (Антонић 2005: 149). Генитив с предлогом близу садржи податак о проксималности (Антонић 2005: 148). Акузатив с предлогом уз по правилу се јавља уз динамичне глаголе, али се, ређе, може појавити и уз неке глаголе с обележјем динамичност (-) када се ради о „значењу посредне просторне локализације са обележјем просторне удаљености типа проксималност (непосредна близина)" (Антонић 2005: 216). ${ }^{7}$ Могућност комбиновања акузатива с предлогом уз с глаголима мировања бележи и Н. Арсенијевић (2003:

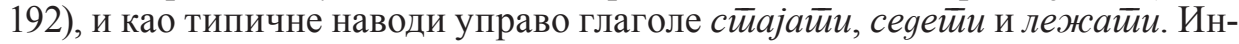
струменталом с предлогом за имплицира се значење 'поред', именицама се

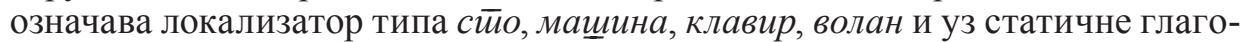
ле формирају ‘идиоматизоване структуре’ (Антонић 2005: 249).

(27) Állok az ablaknál...

(27a) Стојим поред прозора...

(28) Álltunk a kútnál...

(28а) Стајали смо код бунара...

${ }^{7}$ И Антонић (2005: 216) сматра да је данас ова конструкција с наведеним значењем рет-

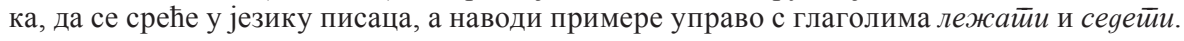


(29) Ülök az asztalnál...

(30) ...ült a lábánál...

(31) ...a lábánál fekszik...

(32) Itt feküdt, a küszöbnél... (29a) Седим за столом...

(30а) ...седео му је крај ногу...

(31a) ...лежи му уз ногу...

(32a) ...лежао је овде, поред прага...

5.1.4. Постпозицијом mellett означава се шири степен спољашњих просторних односа. Нешто се налази поред именице којој се постпозиција прикључује. Еквиваленти су јој конструкције йореg/краj + генитив. Генитивом с наведеним предлозима означава се неусмереност у простору, а обзиром на критеријум статичан/динамичан глагол предлози крај и йореg су необележени (Антонић 2005: 149).

(33) Az ágy mellett áll.

(34) A felesége mellett állt...

(35) Ül az ágy mellett.

(36) A soför mellett ültem...

(37) Feküdtem Anna mellett...

(38) Miklós az öccse mellett feküdt... (33а) Стоји поред кревета.

(34а) Стајао је поред своје жене...

(35а) Седи поред кревета.

(36а) Седео сам поред возача...

(37a) Лежао сам поред Ане...

(38а) Миклош је лежао поред свог млађег брата...

5.1.5. Постпозицијом alatt означава се шири степен спољашњих месних односа. Нешто се налази испод именице којој се постпозиција прикључује. Еквиваленти су јој конструкције $u c \bar{u} o g+$ генитив и $\bar{u} o g+$ инструментал. Генитив с предлогом исйоg неутралан је с обзиром на обележја место целог тока предикације, адлативност, аблативност и перлативност (Антонић 2005: 150). Инструментал с предлогом $\bar{u} о g$, за разлику од конструкције с генитивом, има обележје место целог тока предикације (+) (Антонић 2005: 250). Имајући у виду семантику управног глагола, у примерима који следе наведене конструкције могу се сматрати синонимичним. ${ }^{8}$

(39) ...állnak a nagy fa alatt...

(40) Álltak hárman egy esernyő alatt...

(41) Bender a napernyő alatt ül...

(42) A barackfa alatt ültünk...

(43) ...pontosan a polc alatt fekszik.

(44) Sárga takaró alatt feküdt... (39a) ...стоје испод великог дрвета...

(40а) Троје их је стајало под једним кишобраном...

(41a) Бендер седи испод сунцобрана...

(42а) Седели смо испод дрвета кајсије...

(43a) ...лежи тачно испод полице.

(44a) Лежао је испод жутог покривача...

5.1.6. Постпозицијом felett (fölött) означава се шири степен спољашњих месних односа. Нешто се налази изнад именице којој се постпозиција при-

\footnotetext{
${ }^{8}$ Ова констатација важи и за одељке 5.1.6., 5.1.7., 5.1.8. и 5.1.9. овога рада. Синонимичним се могу сматрати спацијални генитив с предлозима ucūog, изнаg, исйpeg, иза, између и спацијални инструментал с предлозима $\bar{u} o g$, hag, $\bar{u} p e g, з a$, мeђу уз индирективне глаголе $c \bar{u} a j a \bar{u} u$, сеgетии и лежайи.
} 
кључује. Еквиваленти су јој конструкције изнаg + генитив и наg + инструментал. И генитив с предлогом изнаg неутралан је с обзиром на обележја место целог тока предикације, адлативност, аблативност и перлативност (Антонић 2005: 150). Инструментал с предлогом нag, за разлику од конструкције с генитивом, има обележје место целог тока предикације (+) (Антонић 2005: 250).

(45) ...áll a koporsó felett...

(46) Álltak a sír fölött...

(47) Közvetlenül a víz fölött ülünk...

(48) ...ott ült hajdani városok felett...

(49) Vattás köd feküdt a nádasok felett.

(50) .... kabala fölött oldalra kinyúlva feküdt. (45а) ...стоји над ковчегом...

(46а) Стајали су над гробом...

(47a) Седимо тачно изнад воде...

(48a) ...седео је тамо изнад некадашњих градова...

(49a) Магла као вата лежала је над тршчаком.

(50а) ...лежао је над кабалом, испружен постранце.

5.1.7. Постпозицијом elött означава се шири степен спољашњих месних односа. Нешто се налази испред именице којој се постпозиција прикључује. Еквиваленти су јој конструкције исйpeg + генитив и $\bar{u} p e g+$ инструментал. Генитив с предлогом исйреg такође је неутралан с обзиром на обележја место целог тока предикације, адлативност, аблативност и перлативност (Антонић 2005: 150). Инструментал с предлогом $\bar{u} p e g$, за разлику од конструкције с генитивом, има обележје место целог тока предикације (+) (Антонић 2005: 250).

(51) ...az ajtó előtt áll...

(52) A ház elött álltam...

(53) Ülök a tévé előtt...

(54) ...ült a kályha előtt...

(55) ...ott fekszik a kút elött.

(56) ...a zárt kávéház előtt feküdtek. (51a) ...стоји пред вратима...

(52а) Стајао сам испред куће..

(53а) Седим испред телевизора...

(54a) ....едео је испред пећи...

(55a) ...лежи тамо испред бунара.

(56а) ...лежали су испред затворене кафане.

5.1.8. Постпозицијом mögött означава се шири степен спољашњих месних односа. Нешто се налази иза именице којој се постпозиција прикључује. Еквиваленти су јој конструкције иза + генитив и з $a+$ инструментал. Генитив с предлогом иза такође је неутралан с обзиром на обележја место целог тока предикације, адлативност, аблативност и перлативност (Антонић 2005: 150). Инструментал с предлогом за, за разлику од конструкције с генитивом, има обележје место целог тока предикације (+) (Антонић 2005: 250).

(57) A hátam mögött állnak...

(58) ...álltam az ajtó mögött... (57a) Стоје ми иза леђа...

(58а) Стајао сам иза врата... 
(59) A taxis mögött ül...

(60) A hátad mögött ültünk...

(61) A ház mögött fekszik a napon.

(62) A nő a férfi mögött feküdt... (59а) Седи иза таксисте...

(60а) Седели смо ти иза леђа...

(61a) Лежи на сунцу иза куће.

(62а) Жена је лежала иза мушкарца...

5.1.9. Постпозицијом között $(k \ddot{z z} t)$ означава се унутрашњи месни однос, тј. да се нешто налази између именица уз које стоји. Српски еквиваленти овакве мађарске структуре су између + генитив или међу + инструментал. Обе конструкције сврстане су у средства за исказивање неусмерености. Сматра се да генитив с предлогом између може бити замењен инструменталом с предлогом међу „уз напомену да код генитива поред идентификације места постоји и представа о одмеравању места према крајњим границама с обе стране, а инструменталом се остварује искључиво идентификација места без представе о оваквом одмеравању" (Антонић 2005: 149-150).

(63) ...hogy ne a nevelők közt álljon...

(64) ...ott állt a két író közt...

(65) Ott ül a jövendő nászai között...

(66) Közte és a magas néger között ültem.

(67) ...két férfi között egy szőke hajú nő fekszik.

(68) A ceruzák, bögrék, kanalak között feküdtek... (63a) ...да не би стајао међу васпитачима...

(64a) ...стајао је између два писца...

(65a) Седи тамо међу будућим пријатељима...

(66а) Седео сам између њега и високог црнца.

(67a) ...између два мушкарца лежи једна плавуша.

(68а) Лежали су међу оловкама, шољама, кашикама...

5.1.10. Постпозицијом körül означава се шири степен спољашњих месних односа. Нешто се налази око именице којој се постпозиција прикључује. Еквивалент јој је конструкција око + генитив, којом се, по правилу, означава неусмереност у простору.

(69) Egyre többen állnak a lány körül. (69a) Све више њих стоји око девојке.

(70) Az asztal körül álltak..

(70а) Стајали су око стола...

(71) Ülnek a láng körül.

(71a) Седе око ватре.

(72) Az asztal körül ültünk...

(72а) Седели смо око стола...

(73) ...fekszenek a kihamvadt tüz körül. (73a) ...леже око угашене ватре.

(74) ...feküdtek a tábor körül...

(74a) ...лежали су око кампа...

5.2. ЛАТИВНЕ/АДЛАТИВНЕ КОНСТРУКцИЈЕ. Парадигма могућих српских еквивалената сложенија је у овој групи у односу на претходну. Наиме, оствариве

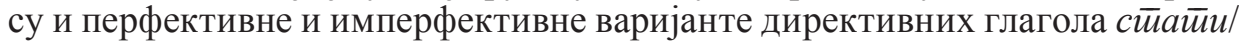

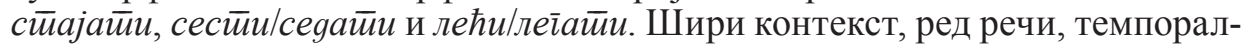
ни модификатори, интонација поузданије би разрешили ову дилему, али су у раду издвојени минимални реченични модели, те остаје могућност за 
различиту интерпретацију. Начелно се може рећи да је перфективна варијанта резервисана за ситуацију у прошлом времену, а имперфективна за ситуацију актуелну у моменту говора,${ }^{9}$ стога ће се оне узети као еквиваленти. Оно што обједињује обе варијанте јесте обележје директивности, у питању су динамични глаголи, перфективност/имперфективност глагола не утиче на тип спацијалне одредбе.

5.2.1. Наставком - $b a /$-be (наставак за илатив) означава се унутрашњи просторни однос, тачније да се нешто из спољњег простора креће ка унутрашњости. Стоји уз динамичне глаголе. У српском му је типичан еквивалент конструкција $y+$ акузатив, којом се обележава усмереност, приближавање локализатору с податком о досезању циља. Глагол носи обележја динамичност $(+)$ и директивност $(+)$, а предлог $y$ показује да је циљ унутрашњост локализатора (Антонић 2005: 213).

(75) Patrick Roy áll a kapuba...

(75a) Патрик Роа стаје у гол...

(76) A civilruhás a sarokba állt...

(76а) Човек у цивилу стао је у ћошак...

(77) ...a fotelba ül...

(77а) ....еда у фотељу...

(78) ...taxiba ültünk...

(78a) ...сели смо у такси...

(79) ...ágyába fekszik...

(79a) ...леже у кревет...

(80) ...fübe feküdt...

(80а) ...легао је у траву...

5.2.2. Наставком -ra/-re (наставак за сублатив) означава се спољашњи просторни однос. Изражава кретање, усмереност ка површини појма исказаног сублативом и крајњи циљ кретања. Најчешћи еквивалент му је у српском конструкција $н а+$ акузатив, која има обележја идентична претходном моделу, с тим да предлог на показује да је циљ, најчешће, горња површина локализатора (Антонић 2005: 213).

(81) ...a párkányra áll...

(82) A nagy Tiborc a vállára állt...

(83) .... földre ül...

(84) .... küszöbre ült.

(85) ...hasra fekszik...

(86) ....az ágyra feküdtem... (81a) ...стаје на симс...

(82а) Велики Тиборц му је стао на рамена...

(83а) ....еда на земљу...

(84a) ...сео је на праг.

(85a) ...леже на стомак...

(86а) ....егегоо сам на кревет...

${ }^{9}$ Колики је уплив контекста, неких синтаксичких елемената, али и специфичних правила посматраних језика, а који могу утицати на различиту интерпретацију, илустроваћу с неколико примера. У мађарском се презент често употребљава за исказивање будућности, док је у српском чешћи футур, имперфективном ӥl одговара перфективно сестии: ...majd vasárnap

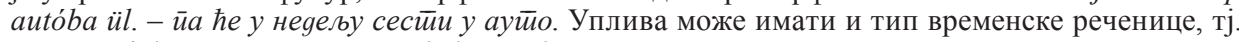
одговарајући везник: ...amig a helyére ültem... - ...gок сам сеgао на њеі̄ово местио..; ...amint a pianínó elé állt. - чим је cūao üpeg йијанино. Утицај временске одредбе показују следећи примери: ...mert gyakran lóra ültek. - ...jep су честио сеgали на коње; ...hasra is feküdt egyszer... ...јеgном је леїао и на стиомак... 
5.2.3. Наставком -hoz/-hez/-höz (наставак за алатив) означава се шири степен спољашњих месних односа. Карактерише га усмереност кретања или вршења неке радње ка близини неког појма. У српском су му еквиваленти

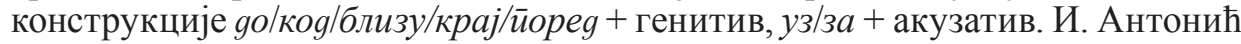
(2005) генитив с овим предлозима сврстава у конструкције којима се исказује неусмереност, док код С. Павловића (2006) налазимо да су директивно неутрални (уп. тачку 4.1.3. овог рада). Акузативом с овим предлозима означава се адлативност. Предлог уз указује на бочну страну „првенствено када је живи локализатор, или неспецификована страна, када је неживи локализатор" (Антонић 2005: 215). И. Антонић напомиње да предлог уз употребљен уз вертикалне локализаторе носи обележје просторне удаљености типа проксималност (непосредна близина). Предлогом за означава се задња страна локализатора. И. Антонић (2005: 215) примећује да је та конструкција врло ретка у савременом језику, али да се доследно задржава уз локализаторе

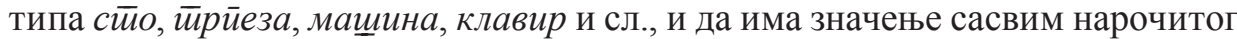
просторног односа.

(87) A falhoz állnak...

(88) A kerítéshez állt.

(89) A lábához ül...

(90) A zongorához ültem...

(91) Hozzám fekszik...

(92) ...aztán egymáshoz feküdtek... (87a) Стају до зида...

(88а) Стао је уз ограду.

(89a) Седа му уз ногу...

(90а) Сео сам за клавир...

(91a) Леже поред мене...

(92a) ...онда су легли једно уз друго...

5.2.4. Постпозицијом mellé означава се да је нешто усмерено да заузме место поред именице уз коју стоји. Еквиваленти су јој йоpeg/крај + генитив и з $^{+}$акузатив. Проблем исказивања адлативности генитивном конструкцијом примећује Е. Андрић (ANDRIĆ 2002: 89) која, у недостатку једнозначног еквивалента, нуди прецизирање у загради: $(g o) \bar{u} o p e g+$ генитив. Акузатив с предлогом уз карактерише усмереност адлативног типа, глагол носи обележје динамичност $(+)$ и директивност $(+)$, а оријентир је бочна страна локализатора (Антонић 2005: 215).

(93) Abed az ágya mellé áll...

(93a) Абед стаје поред њеног кревета...

(94) Adam a zongora mellé állt...

(94а) Адам је стао поред клавира...

(95) ...az ablak mellé ülünk.

(95а) ...седамо поред прозора.

(96) A detektív mellé ült.

(96а) Сео је поред детектива.

(97) ...és az ura mellé fekszik.

(97a) ...и леже поред господара.

(98) A ló mellé feküdt...

(98а) Легао је поред коња...

5.2.5. Постпозицијом alá означава се да је нешто усмерено испод именице уз коју стоји. Еквиваленти су му иcйog + генитив и $\bar{u} o g+$ акузатив. Генитив с предлогом $u c \bar{u} о g$ неутралан је с обзиром на обележја место целог тока предикације, адлативност, аблативност и перлативност (Антонић 2005: 150). Е. Андрић (ANDRIĆ 2002: 89) нуди прецизирање у загради: (go)ucūog + 
генитив. Акузатив с предлогом $\bar{u} о g$ карактерише усмереност адлативног типа, глагол носи обележје динамичност (+) и директивност (+), а оријентир је доња страна локализатора (Антонић 2005: 215). Имајући у виду семантику управног глагола, у примерима који следе наведене конструкције могу се сматрати синонимичним. ${ }^{10}$

(99) Gyorsan a Mária-kép alá áll...

(99а) Стаје брзо испод слике Марије...

(100) A fa alá állt...

(101) Ülök a híd alá...

(102) ...és az ablak alá ült...

(103) ...éjjel az ágy alá feküdtem...

(100а) Стао је под дрво...

(101a) Седам испод моста...

(102а) ...па је сео испод прозора...

(104) A véreb a kocsi alá feküdt...

(103a) ...ноћу сам легао под кревет...

(104a) Ловачки пас је легао под кола...

5.2.6. Постпозицијом fölé означава се да је нешто усмерено изнад именице уз коју стоји. Еквиваленти су јој је изнаg + генитив и нag + акузатив. Генитив с предлогом изнаg неутралан је с обзиром на обележја место целог тока предикације, адлативност, аблативност и перлативност (Антонић 2005: 150). Е. Андрић (ANDRIĆ 2002: 89) нуди прецизирање у загради: (go)uзнаg + генитив. Акузатив с предлогом $\mathrm{Hag}$ карактерише усмереност адлативног типа, глагол носи обележје динамичност (+) и директивност (+), а оријентир је горња страна локализатора (Антонић 2005: 215).

(105) ...s egy fényes csillag áll a láng fölé. (105a) ...и једна сјајна звезда стаје изнад пламена.

(106) Felesége fölé állt.

(106а) Стао је изнад своје жене.

(107) Garfield (...) a fejem fölé ül a párnára.

(107a) Гарфилд седа изнад моје главе на јастук.

(108) ...forró lavór fölé ültek...

(108а) ...сели су изнад врућег лавора... ${ }^{11}$

5.2.7. Постпозицијом elé означава се да је нешто усмерено испред именице уз коју стоји. Еквиваленти су јој исйpeg + генитив и йpeg + акузатив. Генитив с предлогом исйреg неутралан је с обзиром на обележја место целог тока предикације, адлативност, аблативност и перлативност (Антонић 2005: 150). Е. Андрић (ANDRIĆ 2002: 89) нуди прецизирање у загради: (go)ucūpeg + генитив. Акузатив с предлогом йpeg карактерише усмереност адлативног типа, глагол носи обележје динамичност (+) и директивност (+), а оријентир је предња страна локализатора (Антонић 2005: 215).

(109) ....a tükör elé áll...

(109a) ....стаје пред огледало...

(110) ....autójuk elé állt.

(110а) ....стао је испред њиховог аута...

${ }^{10}$ Ова констатација важи и за одељке 5.2.6., 5.2.7., 5.2.8. и 5.2.9. овога рада. Синонимичним се могу сматрати спацијални генитив с предлозима исйog, изнаg, исйpeg, иза, између и

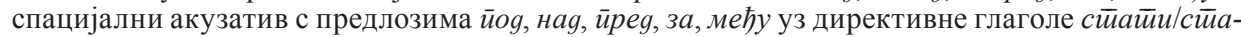

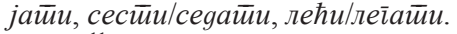

${ }^{11}$ У корпусу није забележен глагол fekszik с постпозицијом fölé. 
(111) ....a tükör elé ül...

(112) ...és a térkép elé ült.

(113) És mégsem fekszem a villamos elé.

(114) A kutyám a lábam elé feküdt. (111a) ...седа испред огледала...

(112а) ...па је сео испред карте.

(113a) Па ипак нећу лећи пред трамвај.

(114a) Пас ми је легао испред ногу.

5.2.8. Постпозицијом mögé означава се да је нешто усмерено иза именице уз коју стоји. Еквиваленти су јој је $и з a+$ генитив и з $a+$ акузатив. Генитив с предлогом иза неутралан је с обзиром на обележја место целог тока предикације, адлативност, аблативност и перлативност (Антонић 2005: 150). E. Андрић (ANDRIĆ 2002: 89) нуди прецизирање у загради: (go)uзa + генитив. Акузатив с предлогом за карактерише усмереност адлативног типа, глагол носи обележје динамичност $(+)$ и директивност $(+)$, а оријентир је задња страна локализатора (Антонић 2005: 215).

(115) Seres háta mögé állok...

(116) ...s Eszter mögé állt.

(117) ....a vezetöülés mögé ülök...

(118) Tímár a lány mögé ült.

(119) Az asszony mögé feküdt... (115а) Стајем иза Шерешевих леђа...

(116а) ...па је стао иза Естере.

(117a) ...седам иза возачевог седишта...

(118а) Тимар је сео иза девојке.

(119а) Легао је иза жене... ${ }^{12}$

5.2.9. Постпозицијом közé означава се унутрашњи месни однос, исказује се да је нешто усмерено између именица иза којих стоји. Еквиваленти су јој између + генитив и међу + акузатив. Проблем исказивања адлативности конструкцијом између + генитив примећује Е. Андрић (ANDRIć 2002: 89) која, у недостатку једнозначног еквивалента, нуди прецизирање у загради: (go)uзмеђy + генитив. Акузатив с предлогом међу карактерише усмереност адлативног типа, глагол носи обележје динамичност $(+)$ и директивност $(+)$. Предлог међу знак је интерлокализације и јавља се у случају више локализатора или делова једног локализатора (Антонић 2005: 215).

(120) Elemér a térdei közé áll.

(121) ...utána állt a hivatásosok közé. (120а) Елемер му стаје између колена.

(121а) ...затим је стао међу професионалце.

(122) Egyik az asztal alá ül (...), Bedzsó a (122a) Један седа испод стола (...), Беџо fal meg a konyhaszekrény közé. између зида и креденца.

(123) Két ág közé ült.

(124) ...sort fekszenek két bokor közé...

(125) ....a végén néhány fadeszka közé feküdt... (123а) Сео је између две гране.

(124а) ....редом лежу између два жбуна...

(125а) ...на крају је легао између неколико дасака...

5.2.10. Постпозицијом köré означава се да се нешто креће да заузме место око именице уз коју стоји. Еквивалент јој је предлошко-падежна конструкција око + генитив, којом се примарно означава неусмереност, али у

12 У корпусу није забележен пример с глаголом fekszik у презенту с постпозицијом mögé. 
случају посматраних глагола управо њихова семантика показује да је могућа и директивна интерпретација. ${ }^{13}$ Проблем исказивања адлативности овом конструкцијом примећује и E. Андрић (ANDRIć 2002: 89) која, у недостатку једнозначног еквивалента, нуди прецизирање у загради: (go)око + генитив.

(126) ...nemsokára gyürübe állnak a falu (126a) ...ускоро ће стати укруг око села. köré.

(127) Nagy tisztelettel álltak (...) HULAF (127a) С великим поштовањем стали BILGERLAND köré. су око HULAF BILGERLAND-a.

(128) ...és a terített asztal köré ülnek.

(129) Ismét a kisasztal köré ültünk...

(128а) ...па седају око постављеног стола.

(129а) Поново смо сели око сточића...

6. ЗАКљУчАК. На основу овога што је приказано може се рећи да на директивност мађарских глагола áll, ül и fekszik непосредно утиче тип спаци-

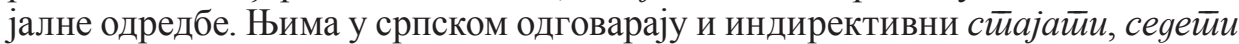
и лежсай

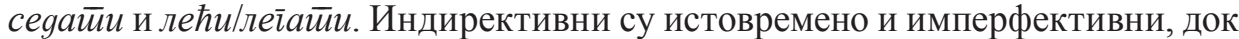
директивни, у зависности од темпоралне ситуације и других синтаксичких елемената, могу бити и перфективни и имперфективни.

Недвосмислено индирективне спацијалне конструкције су: локатив с предлозима $y$ и на, инструментал с предлозима за, међу, йog, ūpeg и нag, које се остварују уз имперфективне глаголе стиајайи, сеgетии и лежайи. Недвосмислено директивне конструкције и то лативног/адлативног типа предста-

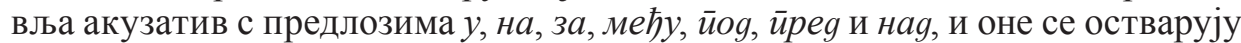

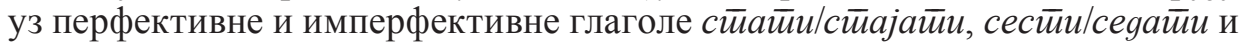
лећи/лет̆айи. Остале забележене могућности су необележене с обзиром на критеријум директивности. Тако је генитив с предлозима исйоg, ucūpeg, uзнag, иза, коg, близу, крај, gо (са значењем близу), йореg, између и око необележен, као и акузатив с предлогом уз, стога се остварују уз све наведене глаголе.

На крају се може констатовати да у мађарском језику тип спацијалне одредбе једнозначно одређује семантику посматраних глагола, те има уплива и на аспекатску интерпретацију реченице, за разлику од српског у којем постоје и оне предлошко-падежне конструкције на основу којих се не могу предвидети обележја глагола. Да ли ће спој глагола и спацијалне одредбе имати обележје директивности/индирективности у тим случајевима зависи од семантике управног глагола.

ИЗВОР

Mazsola - a magyar igei bővitményszerkezet vizsgálata. corpus.nytud.hu/cgi-bin/mazsola/mazsola hun.pl

${ }^{13}$ И. Антонић наводи пример Деца су йосеgала око стиола (2005: 149). 


\section{ЦИТИРАНА ЛИТЕРАТУРА}

Антонић, Ивана. Синтакса и семантика падежа. Предраг Пипер, Ивана Антонић, Владислава Ружић, Срето Танасић, Људмила Поповић, Бранко Тошовић. Синйакса савременоїа срйской језика. Простиа речениия. Београд - Нови Сад: Институт за српски језик САНУ - Београдска књига - Матица српска, 2005, 119-300.

Арсенијевић, Нада. Акузатив с предлогом у савременом српском језику (I). Зборник Майице срйске за филолоїију и линївисииику XLVI/1 (2003): 107-263.

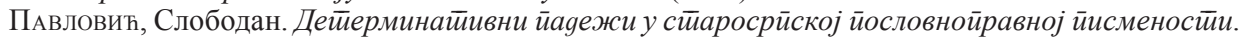
Нови Сад: Матица српска, 2006.

Пипер, Предраг. Семантичке категорије у простој реченици: Синтаксичка семантика. Предраг Пипер, Ивана Антонић, Владислава Ружић, Срето Танасић, Људмила Поповић, Бранко Тошовић. Синйакса савременоїа срйской језика. Простй реченица. Београд - Нови Сад: Институт за српски језик САНУ - Београдска књига - Матица српска, 2005, 575-982.

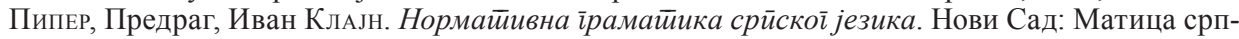
ска, 2013.

ANDRIĆ, Edita. Leksikologija i morfologija mađarskog jezika. Novi Sad: Filozofski fakultet, Odsek za hungarologiju, 2002.

ANDRIĆ, Edita. Struktura sintagmi i rečenica u savremenom mađarskom jeziku. Novi Sad: Filozofski fakultet, Odsek za hungarologiju, 2008.

Forgács, Tamás. A valenciaelmélet nyelvtörténeti alkalmazásának elméleti és gyakorlati kérdései. Szeged, 1996. <https://core.ac.uk>

Keszler, Borbála. A határozók. Balog Judit, Haader Lea, Keszler Borbála et al. Magyar grammatika. Budapest: Nemzeti Tankönykiadó, 2000, 423-443.

Kiefer, Ferenc. Az aspektus és a mondat szerkezete. In: Bánréti Zoltán, Kenesei István, Kiefer Ferenc, É. Kiss Katalin et. al. Strukturális magyar nyelvtan. 1. kötet. Mondattan. Budapest: Akadémiai Kiadó, 2015, 729-809. <http://www.nytud.mta.hu > smny > mondattan>

Mrazović, Pavica, Zora Vukadinović. Gramatika srpskog jezika za strance. Sremski Karlovci - Novi Sad: Izdavačka knjižarnica Zorana Stojanovića, 2009.

NÉMETH, Boglárka. Az aspektus a magyar nyelvben. Különos tekintettel a statikusságra. Segédkönyvek a nyelvészet tanulmányozásához 144. Budapest: Tinta Könyvkiadó, 2012.

Sipos, Mária. 2 in 1 - A szinjai hanti lokatív mondatok egyik kvázikopulájáról. In: Forgács Tamás, Németh Miklós, Sinkovics Balázs szerk. A nyelvtörténeti kutatások újabb eredményei X. Szeged: SZTE BTK Magyar Nyelvészeti Tanszék, 2019, 299-310.

VAJDA, Jožef. Padežne mesne $i$ vremenske konstrukcije. Kontrastivna gramatika srpskohrvatskog $i$ mađarskog jezika 4. Novi Sad: Institut za hungarologiju, 1976.

Dušanka Zvekić-Dušanović

\section{ON SOME ASPECTUAL ALTERNATIONS IN HUNGARIAN AND SERBIAN}

\section{Su m m a ry}

This paper analyzes a segment of the problematics concerning verb aspect and Aktionsart in the relation Hungarian - Serbian: the Hungarian verbs expressing bodily posture áll, ül and fekszik, whose Serbian counterparts are indirective verbs stajati, sedeti and ležati, but also the directive ones stati/stajati, sesti/sedati i leći/legati. The analysis is focused on the influence of the types of spatial adjuncts on the semantic interpretation of the aforementioned Hungarian verbs, which determine the sentential aspect. The author concludes that the type of spatial adjunct determines the directivity of the verbs áll, $\ddot{u} l$ and fekszik. The Serbian indirective equivalents are imperfective, while the directive ones, depending on the temporal situation and other syntactic elements, can be both perfective and imperfective. The type of spatial adjunct in Hungarian determines semantics of the analyzed verbs, thus influencing the aspectual interpretation of a sentence. Constructions which exhibit a 
mutual influence of verb semantics and a spatial adjunct in Serbian are identified, as well as prepositional phrases with spatial meaning on the basis of which a verbal meaning cannot be determined, thus the interpretation depends on the semantics of the predicate.

Универзитет у Новом Саду

Филозофски факултет

Одсек за српски језик и лингвистику

Др Зорана Ђинђића 2, 21000 Нови Сад, Србија

dusazd@ff.uns.ac.rs
(Примљено: 16. августа 2021;

прихваћено: 28. октобра 2021) 